\title{
Twelve new compounds from the basidiomycete Boreostereum vibrans
}

\author{
Jian-Hai Ding, ${ }^{\mathrm{a}, \mathrm{b}, \mathrm{c}}$ Tao FenG, ${ }^{\mathrm{a}}$ Zheng-Hui LI, ${ }^{\mathrm{a}}$ Liang LI, ${ }^{\mathrm{b}}$ and Ji-Kai LiU ${ }^{\mathrm{a}, *}$ \\ ${ }^{a}$ State Key Laboratory of Phytochemistry and Plant Resources in West China, Kunming Institute of Botany, Chinese \\ Academy of Sciences, Kunming 650201, China \\ ${ }^{\mathrm{b}}$ School of Chemical Science and Technology, Yunnan University, Kunming 650091, China \\ ${ }^{\mathrm{c}}$ Graduate University of Chinese Academy of Sciences, Beijing 100049, China
}

Received 18 July 2012; Accepted 4 September 2012

(C) The Author(s) 2012. This article is published with open access at Springerlink.com

\begin{abstract}
Seven cadinane sesquiterpenoids, named boreovibrins A-G (1-7), three dihydrobenzofurans (8-10), and two lactones (11 and 12), together with one known compound (13), were isolated from cultures of the basidiomycete Boreostereum vibrans. The new structures were elucidated by means of spectroscopic methods. Compounds $\mathbf{5}, \mathbf{6}$, and $\mathbf{1 1}$ showed weak inhibitory activities against isozymes of $11 \beta$-hydroxysteroid dehydrogenases (11 $\beta$-HSD).
\end{abstract}

Keywords: cadinane, sesquiterpenoid, boreovibrin, dihydrobenzofuran, lactone, Boreostereum vibrans

\section{Introduction}

Boreostereum vibrans is entitled as one of talent strains due to the discovery of a series of vibralactone derivatives. ${ }^{1-4}$ Of them, vibralactone showed significant inhibitory activity against pancreatic lipase with an $\mathrm{IC}_{50}$ value of $0.4 \mu \mathrm{g} / \mathrm{mL},{ }^{1}$ and its total synthesis has also been achieved. ${ }^{5}$ Vibralactone was also used as a tool to study the activity and structure of the CIpP1P2 complex from Listeria monocytogenes. ${ }^{6}$ Currently, our chemical study on the little modified cultivation conditions of the same source has led to the isolation of several different types of compounds, including seven new cadinane sesquiterpenoids, boreovibrins A-G (1-7), three new dihydrobenzofurans $(\mathbf{8}-\mathbf{1 0})$, and two new lactones (11 and 12). Their structures were established by extensive spectroscopic data analysis. Meanwhile, a known compound was identified as 5(1",2"-dihydroxypropyl)-2-isopropenyl-2,3-dihydrobenzofuran (13) by comparison with data in the literature. ${ }^{7}$ Compounds 2 , 3, 6, 8, 10, and 13 were evaluated for their cytotoxicities against five human cancer cell lines. The inhibitory effects of all the compounds on isozymes of $11 \beta$-hydroxysteroid dehydrogenases which catalyze the interconversion of active cortisol and inactive cortisone were also investigated.

\section{Results and Discussion}

Compound 1, a colorless oil, showed a molecular ion peak in the HREIMS at $m / z 252.1729[\mathrm{M}]^{+}$, analyzing for $\mathrm{C}_{15} \mathrm{H}_{24} \mathrm{O}_{3}$ with four degrees of unsaturation. The IR spectrum showed absorption bands attributable to hydroxy $\left(3431 \mathrm{~cm}^{-1}\right)$ and carboxyl $\left(1707 \mathrm{~cm}^{-1}\right)$ groups. The ${ }^{13} \mathrm{C}$ NMR spectrum

*To whom correspondence should be addressed. E-mail: jkliu@mail.kib.ac.cn

\section{望 Springer}
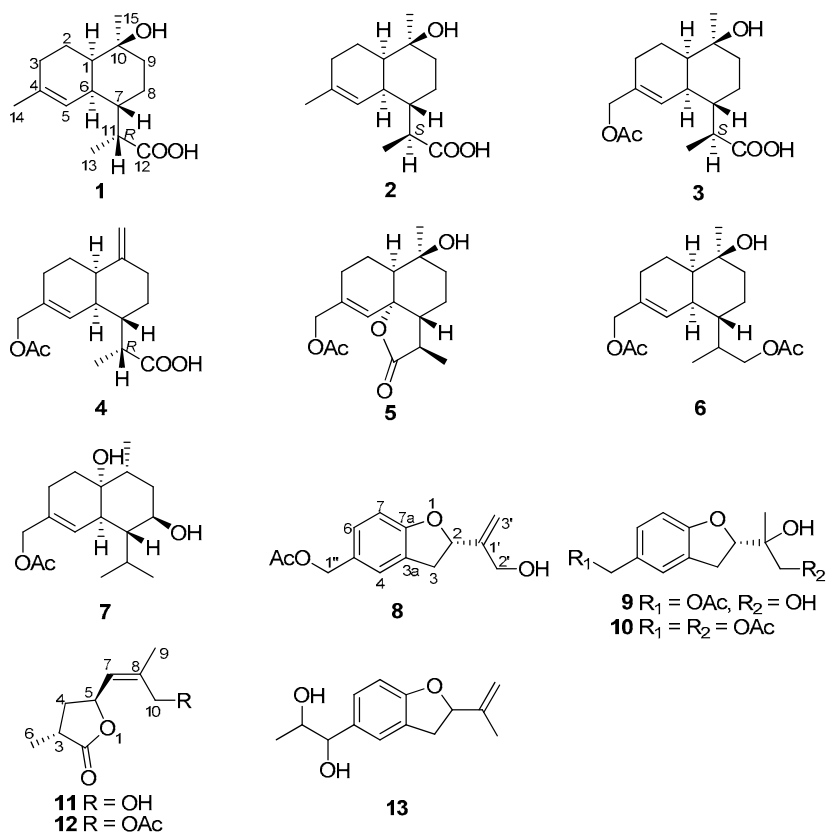

13

displayed 15 carbon signals for a carboxyl carbon, a trisubstituted double bond, an oxygenated $\mathrm{sp}^{3}$ quaternary carbon, four methylenes, four methines, and three methyls (Table 1). Beyond two degrees of unsaturation occupied by one double bond and a carboxyl carbon, compound 1 was required to possess a bicyclic system. In the ${ }^{1} \mathrm{H}-{ }^{1} \mathrm{H}$ COSY spectrum, a long chain was established as shown in Figure 1. In addition, preliminary analyses of HMBC correlations suggested that compound $\mathbf{1}$ was a cadinane sesquiterpenoid closely related to $\delta$-cadinol. ${ }^{8}$ Further analyses of 2D NMR data 
Table $1 .{ }^{13} \mathrm{C}$ NMR data for compounds $1-7$

\begin{tabular}{|c|c|c|c|c|c|c|c|}
\hline position & 1 & 2 & 3 & 4 & 5 & 6 & 7 \\
\hline 1 & $45.5(\mathrm{~d})$ & 46.7 (d) & $45.2(\mathrm{~d})$ & 44.1 (d) & 44.1 (d) & 45.7 (d) & $72.4(\mathrm{~s})$ \\
\hline 2 & $18.4(\mathrm{t})$ & $19.2(\mathrm{t})$ & $17.8(\mathrm{t})$ & $25.3(\mathrm{t})$ & $18.1(\mathrm{t})$ & $18.3(\mathrm{t})$ & $21.6(\mathrm{t})$ \\
\hline 3 & $31.2(\mathrm{t})$ & $31.9(\mathrm{t})$ & $26.9(\mathrm{t})$ & $27.1(\mathrm{t})$ & $24.2(\mathrm{t})$ & $27.4(\mathrm{t})$ & $22 . .7(t)$ \\
\hline 4 & $135.8(\mathrm{~s})$ & $136.1(\mathrm{~s})$ & $134.9(\mathrm{~s})$ & $134.6(\mathrm{~s})$ & $145.9(\mathrm{~s})$ & $134.5(\mathrm{~s})$ & $132.9(\mathrm{~s})$ \\
\hline 5 & $123.9(\mathrm{~d})$ & $124.6(d)$ & $127.2(\mathrm{~d})$ & $128.9(\mathrm{~d})$ & $124.5(\mathrm{~d})$ & $128.7(\mathrm{~d})$ & $127.2(\mathrm{~d})$ \\
\hline 6 & $37.0(d)$ & $36.8(d)$ & 36.1 (d) & $40.5(\mathrm{~d})$ & $81.0(\mathrm{~s})$ & $36.3(d)$ & 46.1 (d) \\
\hline 7 & 43.3 (d) & 41.8 (d) & 40.5 (d) & 44.1 (d) & $49.6(d)$ & $40.2(d)$ & $55.3(\mathrm{~d})$ \\
\hline 8 & $24.8(\mathrm{t})$ & $24.3(\mathrm{t})$ & $23.8(\mathrm{t})$ & $29.6(t)$ & $18.7(t)$ & $22.7(\mathrm{t})$ & 71.1 (d) \\
\hline 9 & $35.3(\mathrm{t})$ & $35.7(\mathrm{t})$ & $34.8(\mathrm{t})$ & $31.9(\mathrm{t})$ & $34.9(\mathrm{t})$ & $35.2(\mathrm{t})$ & $40.9(\mathrm{t})$ \\
\hline 10 & $72.6(\mathrm{~s})$ & $71.4(\mathrm{~s})$ & $71.9(\mathrm{~s})$ & $153.5(\mathrm{~s})$ & $72.7(\mathrm{~s})$ & $72.4(\mathrm{~s})$ & 39.4 (d) \\
\hline 11 & 39.3 (d) & 39.5 (d) & 39.2 (d) & $40.0(\mathrm{~d})$ & 36.9 (d) & 31.9 (d) & 26.7 (d) \\
\hline 12 & $179.4(\mathrm{~s})$ & $177.5(\mathrm{~s})$ & $181.4(\mathrm{~s})$ & $176.5(\mathrm{~s})$ & $178.6(\mathrm{~s})$ & $69.1(\mathrm{t})$ & $19.8(q)$ \\
\hline 13 & $14.9(q)$ & $9.7(q)$ & $9.7(q)$ & $15.4(q)$ & $13.8(q)$ & $11.0(\mathrm{q})$ & $20.9(q)$ \\
\hline 14 & $23.8(q)$ & $23.9(\mathrm{q})$ & $68.2(\mathrm{t})$ & $68.8(\mathrm{t})$ & $67.2(\mathrm{t})$ & $68.9(\mathrm{t})$ & $68.4(\mathrm{t})$ \\
\hline 15 & $28.2(q)$ & $28.5(\mathrm{q})$ & $27.9(\mathrm{q})$ & $107.9(\mathrm{t})$ & $28.3(q)$ & $28.3(q)$ & $15.0(q)$ \\
\hline $12-\mathrm{OCOCH}_{3}$ & & & & & & $21.4(q)$ & \\
\hline $12-\mathrm{OCOCH}_{3}$ & & & & & & $171.4(\mathrm{~s})$ & \\
\hline $14-\mathrm{OCOCH}_{3}$ & & & $20.9(q)$ & $20.9(q)$ & $21.2(q)$ & $21.4(q)$ & $21.2(q)$ \\
\hline $14-\mathrm{OCOCH}_{3}$ & & & $171.3(\mathrm{~s})$ & $170.9(\mathrm{~s})$ & $171.0(\mathrm{~s})$ & $171.7(\mathrm{~s})$ & $171.2(\mathrm{~s})$ \\
\hline
\end{tabular}

indicated the difference was that the methyl of C-12 in $\delta$ cadinol was oxygenated to a carboxyl group at $\delta_{\mathrm{C}} 179.4$ (s, C$12)$ in 1 on the basis of HMBC correlation of $\delta_{\mathrm{H}} 1.15(3 \mathrm{H}, \mathrm{d}, J$ $=7.1 \mathrm{~Hz}, \mathrm{H}-13)$ and $2.81(1 \mathrm{H}, \mathrm{m}, \mathrm{H}-11)$ to $\mathrm{C}-12$, as well as the requirement of MS data. The relative configuration of $\mathbf{1}$ was elucidated by the ROESY experiment. In which, the correlation of $\mathrm{H}-1 / \mathrm{H}-6 / \mathrm{H}-15$ indicated that they were in the same side, while the correlation of H-11/H-6 allowed H-7 to be in the opposite side (Figure 1). The absolute configuration of $\mathrm{C}-11$ was determined by comparison with ${ }^{13} \mathrm{C}$ NMR data of Me-13 with analogues reported in the literature, ${ }^{9}$ in which the ${ }^{13} \mathrm{C}$ NMR shift of Me-13 from $\delta_{\mathrm{C}} 8.0$ to 10.0 suggested the $S$ form of C-11, while from $\delta_{\mathrm{C}} 13.0$ to 16.0 for $R$. ${ }^{9}$ In compound 1, the ${ }^{13} \mathrm{C}$ NMR shift of $\mathrm{C}-13$ at $\delta_{\mathrm{C}} 14.9$ indicated the $R$ form of $\mathrm{C}-11$. Therefore, compound $\mathbf{1}$ was established to be boreovibrin A, as shown.

Compound 2 possessed the same molecular formula as that of 1, while the IR and NMR data (Tables 1 and 2) were also closely related to those of $\mathbf{1}$. Analyses of 2D NMR data still suggested that compound $\mathbf{2}$ had the same planar structure to that of 1 . However, the ${ }^{13} \mathrm{C}$ NMR data for $\mathrm{C}-13$ between the two compounds were quite different as shown in Table 1, which indicated that the absolute configuration of C-11 in 2 should be $S .{ }^{9}$ The ROESY correlations of $\mathrm{H}-1 / \mathrm{H}-6 / \mathrm{H}-15$ and $\mathrm{H}-11 / \mathrm{H}-6$ also elucidated the relative configuration of these chiral carbons to be the same with those of 1 . Thus, compound 2 was approved as boreovibrin $\mathrm{B}$, as shown.

Compound $\mathbf{3}$ was isolated as a colorless oil. Its molecular formula $\mathrm{C}_{17} \mathrm{H}_{26} \mathrm{O}_{5}$ was determined by the HRESIMS at $\mathrm{m} / \mathrm{z}$ $333.1672[\mathrm{M}+\mathrm{Na}]^{+}$. The NMR data (Tables 1 and 2) were very similar to those of $\mathbf{2}$ except for the methyl of C-14 in $\mathbf{2}$ was oxygenated to a hydroxymethylene $\left(\delta_{\mathrm{C}} 68.2, \mathrm{t}\right)$ in $\mathbf{3}$ as indicated by the HMBC correlation of $\delta_{\mathrm{H}} 4.46(2 \mathrm{H}$, br. s, H-14) with C-4. In addition, the acetoxylation of the hydroxymethylene was established by the HMBC correlation from $\delta_{\mathrm{H}} 4.46$ (br. s, H-14) to $\delta_{\mathrm{C}} 171.3$ (s, OAc). Analysis of the ROESY spectrum and the comparison of ${ }^{13} \mathrm{C}$ NMR data of C13 established the stereoconfiguration of $\mathbf{3}$ the same as that of 2. Hence, compound $\mathbf{3}$ was identified as boreovibrin $\mathrm{C}$.

Compound $\mathbf{4}$ was obtained as a colorless oil. Its molecular formula was established as $\mathrm{C}_{17} \mathrm{H}_{24} \mathrm{O}_{4}$ by the negative HRESIMS at $\mathrm{m} / z 291.1589[\mathrm{M}-\mathrm{H}]^{-}$(calcd for 291.1596). The IR spectrum showed absorption bands at $3424 \mathrm{~cm}^{-1}$ and
$1739 \mathrm{~cm}^{-1}$, corresponding to hydroxy and carbonyl groups, respectively. The ${ }^{1} \mathrm{H}$ and ${ }^{13} \mathrm{C}$ NMR data (Tables 1 and 2) were very similar to those of $\mathbf{3}$ including the presence of an oxymethylene linked by an acetoxyl group and a carboxyl at $\delta_{\mathrm{C}} 176.5$ (s, C-12). However, a terminal double bond was detected and assigned between $\mathrm{C}-10$ and $\mathrm{C}-15$ by the HMBC correlation from $\delta_{\mathrm{H}} 4.61$ and 4.68 (each $1 \mathrm{H}$, br. s, H-15) to $\delta_{\mathrm{C}}$ 153.5 (s, C-10), 44.1 (d, C-1), and 31.9 (t, C-9). The downfield ${ }^{13} \mathrm{C}$ NMR shift of $\mathrm{C}-13\left(\delta_{\mathrm{C}} 15.4\right.$, q) indicated $\mathrm{R}$ configuration of $\mathrm{C}-11$. Thus, compound 4 was established as boreovibrin $\mathrm{D}$, as shown.

A negative HRESIMS revealed compound 5 to possess the molecular formula $\mathrm{C}_{17} \mathrm{H}_{24} \mathrm{O}_{5}$ by the $[\mathrm{M}-\mathrm{H}]^{-}$peak at $\mathrm{m} / \mathrm{z}$ 307.1554 , indicating six degrees of unsaturation. The IR spectrum suggested the presence of carbonyl $\left(1740 \mathrm{~cm}^{-1}\right)$ and hydroxy $\left(3443 \mathrm{~cm}^{-1}\right)$ groups. Compound 5 had NMR data (Tables 1 and 2) similar to those of $\mathbf{3}$. However, the existence of an oxygenated $\mathrm{sp}^{3}$ quaternary carbon at $\delta_{\mathrm{C}} 81.0(\mathrm{~s})$ in $\mathbf{5}$ indicated the key difference between them. The HMBC correlations from $\mathrm{H}-1, \mathrm{H}-5$, and $\mathrm{H}-7$ to $\delta_{\mathrm{C}} 81.0$ (s) assigned the oxygenated $\mathrm{sp}^{3}$ quaternary carbon to be C-6. By comparison of ${ }^{13} \mathrm{C}$ NMR data with reported in the literature, ${ }^{10}$ as well as the analysis of MS data, compound $\mathbf{5}$ was suggested to possess a $\gamma$-lactone ring as constructed by C-6, C-7, C-11, and C-12. The ROESY correlation observed between $\mathrm{H}-7$ and $\mathrm{Me}-13$ (not observed between H-7 and H-11) not only supported the $\gamma$ lactone ring as deduced above but also elucidated the relative configuration of Me-13 to be the same side with H-7. Detailed analysis of other 2D NMR data suggested that the other parts were the same to those of $\mathbf{3}$. Therefore, compound $\mathbf{5}$ was established as boreovibrin E.

Compound 6, a colorless oil, possessed a molecular formula $\mathrm{C}_{19} \mathrm{H}_{30} \mathrm{O}_{5}$ as established by the HRESIMS at $\mathrm{m} / z$ 361.1995 [M $+\mathrm{Na}]^{+}$. The IR spectrum showed the presence of carbonyl $\left(1739 \mathrm{~cm}^{-1}\right)$ and hydroxy $\left(3455 \mathrm{~cm}^{-1}\right)$ groups. The ${ }^{1} \mathrm{H}$ and ${ }^{13} \mathrm{C}$ NMR data (Tables 1 and 2) of $\mathbf{6}$ showed similar patterns to those of 3. However, the lost of the carboxyl carbon in $\mathbf{3}$ and the presence of an oxymethylene signal $\left(\delta_{\mathrm{C}} 69.1, \mathrm{t}\right)$ in 6 indicated the modification of $\mathrm{C}-12$, which was supported by the HMBC correlation of $\mathrm{H}-11$ to $\mathrm{C}-12$, as well as the ${ }^{1} \mathrm{H}-{ }^{1} \mathrm{H}$ COSY cross peak between $\delta_{\mathrm{H}} 2.10(1 \mathrm{H}, \mathrm{m}, \mathrm{H}-11)$ and 3.93 $(2 \mathrm{H}, \mathrm{d}, J=7.2 \mathrm{~Hz}, \mathrm{H}-12)$. In addition, an additional acetoxy group was connected to $\mathrm{C}-12$ as indicated by the HMBC 
Table 2. ${ }^{1} \mathrm{H}$ NMR data for compounds 1-7

\begin{tabular}{|c|c|c|c|c|c|c|c|}
\hline position & 1 & 2 & 3 & 4 & 5 & 6 & 7 \\
\hline 1 & $1.61(\mathrm{~m})$ & $1.57(\mathrm{~m})$ & $1.69(\mathrm{~m})$ & $2.40(\mathrm{~m})$ & $2.12(\mathrm{~m})$ & $1.65(\mathrm{~m})$ & \\
\hline $2 \mathrm{a}$ & $1.89(\mathrm{~m})$ & $2.04(\mathrm{~m})$ & $2.01(\mathrm{~m})$ & $1.97(\mathrm{~m})$ & $2.18(\mathrm{~m})$ & $2.00(\mathrm{~m})$ & $1.74(\mathrm{~m})$ \\
\hline $2 b$ & $1.51(\mathrm{~m})$ & $1.51(\mathrm{~m})$ & $1.60(\mathrm{~m})$ & $1.45(\mathrm{~m})$ & $2.10(\mathrm{~m})$ & 1.55 (overlapped) & $1.65(\mathrm{~m})$ \\
\hline $3 a$ & $1.98(\mathrm{~m})$ & 1.96 (overlapped) & $2.15(\mathrm{~m})$ & $2.09(\mathrm{~m})$ & $2.53(\mathrm{~m})$ & 2.13 (overlapped) & $2.15(\mathrm{~m})$ \\
\hline $3 b$ & & & $2.03(\mathrm{~m})$ & & $2.01(\mathrm{~m})$ & $2.03(\mathrm{~m})$ & \\
\hline 5 & $5.62(\mathrm{~d}, 4.1)$ & $5.52(\mathrm{~d}, 4.6)$ & $5.76(\mathrm{~d}, 4.9)$ & $6.07(\mathrm{~d}, 5.1)$ & $5.61(\mathrm{~s})$ & $5.81(\mathrm{~d}, 5.2)$ & $5.80(\mathrm{~d}, 5.6)$ \\
\hline 6 & $2.16(\mathrm{~m})$ & $2.03(\mathrm{~m})$ & $2.11(\mathrm{~m})$ & $2.19(\mathrm{~m})$ & & 2.15 (overlapped) & $1.85(\mathrm{~m})$ \\
\hline 7 & $1.58(\mathrm{~m})$ & 1.95 (overlapped) & 2.00 (overlapped) & $1.76(\mathrm{~m})$ & $2.13(\mathrm{~m})$ & 1.56 (overlapped) & $1.22(\mathrm{~m})$ \\
\hline $8 \mathrm{a}$ & $1.66(\mathrm{~m})$ & $1.29(\mathrm{~m})$ & $1.43(\mathrm{~m})$ & $1.84(\mathrm{~m})$ & $1.92(\mathrm{~m})$ & $1.42(\mathrm{~m})$ & $3.61(\mathrm{~m})$ \\
\hline $8 b$ & $1.31(\mathrm{~m})$ & & $1.32(\mathrm{~m})$ & $1.18(\mathrm{~m})$ & $1.71(\mathrm{~m})$ & $1.22(\mathrm{~m})$ & \\
\hline $9 \mathrm{a}$ & $1.58(\mathrm{~m})$ & $1.60(\mathrm{~m})$ & $1.62(\mathrm{~m})$ & $2.19(\mathrm{~m})$ & $1.63(\mathrm{~m})$ & 1.57 (overlapped) & $1.80(\mathrm{~m})$ \\
\hline $9 b$ & $1.51(\mathrm{~m})$ & $1.43(\mathrm{~m})$ & $1.52(\mathrm{~m})$ & & $1.56(\mathrm{~m})$ & $1.52(\mathrm{~m})$ & $1.25(\mathrm{~m})$ \\
\hline 10 & & & & & & & $1.73(\mathrm{~m})$ \\
\hline 11 & $2.81(\mathrm{~m})$ & $2.78(\mathrm{~m})$ & $2.77(\mathrm{~m})$ & $2.78(\mathrm{~m})$ & $2.68(\mathrm{~m})$ & $2.10(\mathrm{~m})$ & $2.16(\mathrm{~m})$ \\
\hline 12 & & & & & & $3.93(\mathrm{~d}, 7.2)$ & $1.06(\mathrm{~d}, 7.1)$ \\
\hline 13 & $1.15(\mathrm{~d}, 7.1)$ & $1.03(\mathrm{~d}, 7.1)$ & $1.10(\mathrm{~d}, 7.1)$ & $1.12(\mathrm{~d}, 7.1)$ & $1.28(\mathrm{~d}, 7.1)$ & $0.90(\mathrm{~d}, 7.0)$ & $1.00(\mathrm{~d}, 7.0)$ \\
\hline $14 \mathrm{a}$ & $1.63(\mathrm{~s})$ & $1.65(\mathrm{~s})$ & 4.46 (br. s) & $4.47(\mathrm{~d}, 12.3)$ & $4.55(\mathrm{~d}, 12.0)$ & $4.46(\mathrm{~s})$ & $4.50(\mathrm{~d}, 12.4)$ \\
\hline $14 \mathrm{~b}$ & & & & $4.43(\mathrm{~d}, 12.4)$ & $4.54(\mathrm{~d}, 12.0)$ & & $4.49(\mathrm{~d}, 12.5)$ \\
\hline $15 \mathrm{a}$ & $1.27(\mathrm{~s})$ & $1.26(\mathrm{~s})$ & $1.31(\mathrm{~s})$ & 4.68 (br. s) & $1.33(\mathrm{~s})$ & $1.31(\mathrm{~s})$ & $0.99(\mathrm{~d}, 6.8)$ \\
\hline $15 \mathrm{~b}$ & & & & 4.61 (br. s) & & & \\
\hline 12-OAc & & & & & & $2.06(\mathrm{~s})$ & \\
\hline 14-OAc & & & $2.07(\mathrm{~s})$ & $2.01(\mathrm{~s})$ & $2.12(\mathrm{~s})$ & $2.08(\mathrm{~s})$ & $2.06(\mathrm{~s})$ \\
\hline
\end{tabular}

correlation from $\mathrm{H}-12$ to $\delta_{\mathrm{C}} 171.4$ (s, OAc). The ROESY correlations of $\mathrm{H}-1 / \mathrm{H}-6 / \mathrm{H}-15$ and $\mathrm{H}-6 / \mathrm{H}-11$ indicated the same relative configuration as that of $\mathbf{3}$. Therefore, compound 6 was elucidated as boreovibrin $\mathrm{F}$.

Compound 7 was obtained as a colorless oil. The molecular formula was found to be $\mathrm{C}_{17} \mathrm{H}_{28} \mathrm{O}_{4}$ by HRESIMS at $\mathrm{m} / \mathrm{z}$ $319.1885[\mathrm{M}+\mathrm{Na}]^{+}$. The IR spectrum showed the presence of hydroxy $\left(3425 \mathrm{~cm}^{-1}\right)$ and carbonyl $\left(1736 \mathrm{~cm}^{-1}\right)$ groups. In the ${ }^{13} \mathrm{C}$ NMR spectrum (Table 1), one acetoxy group was readily identified. Besides, the other fifteen carbons indicated that compound 7 was still a cadinane sesquiterpenoid and displayed some similar patterns to those of 3. The ${ }^{1} \mathrm{H}-{ }^{1} \mathrm{H}$ COSY spectrum displayed two fragments as shown in figure 1 , from which a hydroxy substituted carbon assigned as C-8 $\left(\delta_{\mathrm{C}}\right.$ $71.1, \mathrm{~d})$ and an isopropyl connected to C-7 were established. In addition, an oxygenated $\mathrm{sp}^{3}$ quaternary carbon at $\delta_{\mathrm{C}} 72.4$ (s) was assigned as $\mathrm{C}-1$ on the basis of HMBC correlations from $\mathrm{H}-2, \mathrm{H}-6$, and $\mathrm{H}-10$ to $\mathrm{C}-1$ (Figure 1). Further analysis of HMBC spectrum indicated that the other parts of 7 were the same as those of 3 . The ROESY correlations of $\mathrm{H}-6 / \mathrm{H}-15 / \mathrm{H}-8$ and $\mathrm{H}-6 / \mathrm{H}-11$ indicated $\mathrm{H}-6$ and $\mathrm{H}-8$ in the same side, while $\mathrm{H}-7$ and $\mathrm{H}-10$ in the opposite side. Furthermore, the ROESY correlations of $\mathrm{H}-10 / \mathrm{H}-2 \mathrm{~b}$ and $\mathrm{H}-2 \mathrm{a} / \mathrm{H}-6$ allowed the $\mathrm{OH}$ at C1 to be the same side with $\mathrm{C}-15$. Thus, compound 7 was established as boreovibrin $\mathrm{G}$, as shown.

Compound 8 was obtained as a colorless oil with the molecular formula of $\mathrm{C}_{14} \mathrm{H}_{16} \mathrm{O}_{4}$ based on the HREIMS at $\mathrm{m} / \mathrm{z}$ $248.1037[\mathrm{M}]^{+}$(calcd 248.1049 for $\mathrm{C}_{14} \mathrm{H}_{16} \mathrm{O}_{4}$ ), with seven degrees of unsaturation. The IR absorption bands at 3431 and $1737 \mathrm{~cm}^{-1}$ indicated the presence of $\mathrm{OH}$ and $\mathrm{CO}$ groups. In the ${ }^{1} \mathrm{H}$ NMR spectrum (Table 3$)$, the signals of $\delta_{\mathrm{H}} 7.19(1 \mathrm{H}, \mathrm{s}, \mathrm{H}-$ 4), $7.14(1 \mathrm{H}, \mathrm{d}, J=8.1 \mathrm{~Hz}, \mathrm{H}-6)$, and $6.79(1 \mathrm{H}, \mathrm{d}, J=8.1 \mathrm{~Hz}$, $\mathrm{H}-7)$ are typical for a 1,2,4-trisubstituted benzene ring. An

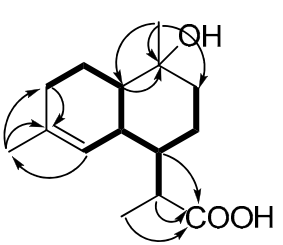

1

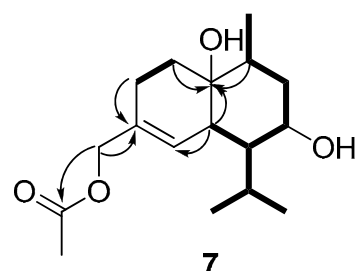

7
${ }^{1} \mathrm{H}-{ }^{1} \mathrm{H}$ COSY

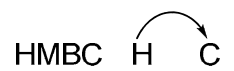

Figure 1. Selected 2D NMR correlations of $\mathbf{1}$ and 7

acetoxy group was identified to be connected to an oxymethylene $\left(\delta_{\mathrm{C}} 66.4, \mathrm{t}, \mathrm{C}-1^{\prime \prime}\right)$ at $\mathrm{C}-5\left(\delta_{\mathrm{C}} 128.4, \mathrm{~s}\right)$ on the basis of HMBC correlations. In addition to these carbons, the ${ }^{13} \mathrm{C}$ NMR spectrum displayed other five carbon resonances ascribable for a terminal double bond, two methylenes (one oxygenated), and one oxygenated methine (Table 3), which were likely to assemble an isopentyl group. All these data indicated that the structure of $\mathbf{8}$ was closely related to that of 5-hydroxymethyl-2-isopropenyl-2,3-dihydrobenzofuran. ${ }^{11}$ The key difference was the additional acetyl $\left(\delta_{\mathrm{C}} 170.5, \mathrm{~s}\right)$ and hydroxymethyl $\left(\delta_{\mathrm{C}} 63.6, \mathrm{t}, \mathrm{C}-2^{\prime}\right)$ groups in $\mathbf{8}$. This assignment was confirmed by the HMBC correlations of $\mathrm{H}-3^{\prime} / \mathrm{C}-2^{\prime}$, and of to $\mathrm{H}-1{ }^{\prime \prime} / \delta_{\mathrm{C}} 170.5$ (s, OAc). Detailed analysis of the 2D NMR data indicated the other parts of $\mathbf{8}$ to be the same as those of 5hydroxymethyl-2-isopropenyl-2,3-dihydrobenzofuran, ${ }^{11}$ while the similarity of specific rotations between $8\left([\alpha]_{\mathrm{D}}^{16}=+18.1\right)$ and 5-hydroxymethyl-2-isopropenyl-2,3-dihydrobenzofuran $\left([\alpha]_{\mathrm{D}}^{21}=+20.8\right)$ indicated the $S$ configuration of C-2. Therefore, compound 8 was elucidated as 5-(1"-acetyloxymethylene)-2hydroxyisopropenyl-2,3-dihydrobenzofuran. 
Table 3. ${ }^{1} \mathrm{H}$ and ${ }^{13} \mathrm{C}$ NMR data for compounds 8-10 ( $\delta$ in ppm and $J$ in $\mathrm{Hz}$ )

\begin{tabular}{|c|c|c|c|c|c|c|}
\hline \multirow[b]{2}{*}{ position } & \multicolumn{2}{|c|}{8} & \multicolumn{2}{|c|}{9} & \multicolumn{2}{|c|}{10} \\
\hline & $\delta_{\mathrm{H}}$ & $\delta_{\mathrm{C}}$ & $\delta_{\mathrm{H}}$ & $\delta_{\mathrm{C}}$ & $\delta_{\mathrm{H}}$ & $\delta_{\mathrm{C}}$ \\
\hline 2 & $5.35(\mathrm{dd}, 9.0,8.9)$ & $83.9(d)$ & $4.86(\mathrm{dd}, 9.5,8.6)$ & $86.2(\mathrm{~d})$ & $4.79(\mathrm{dd}, 9.3,9.2)$ & $86.1(\mathrm{~d})$ \\
\hline \multirow[t]{2}{*}{3} & $3.43(\mathrm{dd}, 15.6,9.0)$ & $35.1(\mathrm{t})$ & $3.43(\mathrm{dd}, 15.6,9.5)$ & $29.8(\mathrm{t})$ & $3.33(\mathrm{dd}, 15.5,9.2)$ & $29.9(\mathrm{t})$ \\
\hline & $3.18(\mathrm{dd}, 15.6,8.9)$ & & $3.18(\mathrm{dd}, 15.6,8.6)$ & & $3.17(\mathrm{dd}, 15.8,9.3)$ & \\
\hline $3 a$ & & $126.9(\mathrm{~s})$ & & $128.9(\mathrm{~s})$ & & $127.1(\mathrm{~s})$ \\
\hline 4 & $7.19(\mathrm{~s})$ & $125.6(\mathrm{~d})$ & 7.20 (br. s) & $126.5(\mathrm{~d})$ & $7.20(\mathrm{~s})$ & $125.6(d)$ \\
\hline 5 & & $128.4(\mathrm{~s})$ & & $129.1(\mathrm{~s})$ & & $128.6(\mathrm{~s})$ \\
\hline 6 & $7.14(\mathrm{~d}, 8.1)$ & $129.1(\mathrm{~d})$ & $7.10(\mathrm{~d}, 8.1)$ & $129.5(\mathrm{~d})$ & $7.13(\mathrm{~d}, 8.0)$ & 129.0 (d) \\
\hline 7 & $6.79(\mathrm{~d}, 8.1)$ & $109.2(\mathrm{~d})$ & $6.66(\mathrm{~d}, 8.1)$ & $109.3(\mathrm{~d})$ & $6.77(\mathrm{~d}, 8.0)$ & $109.2(\mathrm{~d})$ \\
\hline $7 a$ & & $159.5(\mathrm{~s})$ & & $161.1(\mathrm{~s})$ & & $159.9(\mathrm{~s})$ \\
\hline $1^{\prime}$ & & $147.4(\mathrm{~s})$ & & $73.8(\mathrm{~s})$ & & $72.7(\mathrm{~s})$ \\
\hline \multirow[t]{2}{*}{$2^{\prime}$} & $4.28(\mathrm{~d}, 13.5)$ & $63.6(\mathrm{t})$ & $3.66(\mathrm{~m})$ & $67.8(\mathrm{t})$ & $4.33(\mathrm{~d}, 11.3)$ & $68.5(\mathrm{t})$ \\
\hline & $4.25(\mathrm{~d}, 13.5)$ & & $3.56(\mathrm{~m})$ & & $4.13(\mathrm{~d}, 11.3)$ & \\
\hline $3^{\prime}$ & 5.26 (br. s) & $112.5(\mathrm{t})$ & $1.15(\mathrm{~s})$ & $19.7(q)$ & $1.24(\mathrm{~s})$ & $19.9(q)$ \\
\hline $1^{\prime \prime}$ & $5.01(\mathrm{~s})$ & $66.4(\mathrm{t})$ & $4.96(\mathrm{~s})$ & $66.8(\mathrm{t})$ & $5.01(\mathrm{~s})$ & $66.3(\mathrm{t})$ \\
\hline $2^{\prime}-\mathrm{OCOCH}_{3}$ & & & & & $2.13(\mathrm{~s})$ & $20.8(\mathrm{q})$ \\
\hline $2^{\prime}-\mathrm{OCOCH}_{3}$ & & & & & & $171.3(\mathrm{~s})$ \\
\hline $1 "-\mathrm{OCOCH}_{3}$ & $2.08(\mathrm{~s})$ & $21.0(q)$ & $1.99(\mathrm{~s})$ & $21.0(q)$ & $2.08(\mathrm{~s})$ & $21.0(\mathrm{q})$ \\
\hline $1 "-\mathrm{OCOCH}_{3}$ & & $170.5(\mathrm{~s})$ & & $170.9(\mathrm{~s})$ & & $171.5(\mathrm{~s})$ \\
\hline
\end{tabular}

Compound 9 was a colorless oil and gave a molecular formula of $\mathrm{C}_{14} \mathrm{H}_{18} \mathrm{O}_{5}$ by HRESIMS at $\mathrm{m} / z 265.1072[\mathrm{M}-\mathrm{H}]^{-}$ (calcd for 265.1075). The NMR data were similar to those of 8 with the major differences being that the terminal double bond was absent instead of a methyl $\left(\delta_{\mathrm{C}} 19.7, \mathrm{q}, \mathrm{C}-3^{\prime}\right)$ and an oxygenated $\mathrm{sp}^{3}$ quaternary carbon $\left(\delta_{\mathrm{C}} 73.8, \mathrm{~s}, \mathrm{C}-1^{\prime}\right)$ as supported by the HMBC correlations. Compound 9 was determined to be 5-(1"-acetyloxymethylene)-2-(1,2dihydroxyisopropyl)-2,3-dihydrobenzofuran.

Compound $\mathbf{1 0}$ was purified as a colorless oil with the molecular formula of $\mathrm{C}_{16} \mathrm{H}_{20} \mathrm{O}_{6}$ based on the HREIMS at $\mathrm{m} / \mathrm{z}$ $308.1262[\mathrm{M}]^{+}$(calcd for 308.1260). The NMR data (Table 3) of $\mathbf{1 0}$ were very similar to those of $\mathbf{9}$ except for signals of an additional acetoxyl group. This acetoxyl group could be readily identified to be connected to $\mathrm{C}-2^{\prime}$ due to the $\mathrm{HMBC}$ correlation from $\delta_{\mathrm{H}} 4.13$ and 4.33 (each $1 \mathrm{H}, \mathrm{d}, J=11.3 \mathrm{~Hz}, \mathrm{H}-$ $\left.2^{\prime}\right)$ to $\delta_{\mathrm{C}} 171.3(\mathrm{~s}, \mathrm{OAc})$. Therefore, compound $\mathbf{1 0}$ was established as 5-(1"-acetyloxymethylene)-2-(1-O-acetyl-1,2hydroxyisopropyl)-2,3-dihydrobenzofuran.

Compound $\mathbf{1 1}$ was isolated as a colorless oil with the molecular formula of $\mathrm{C}_{9} \mathrm{H}_{14} \mathrm{O}_{3}$ based on the HRESIMS at $\mathrm{m} / \mathrm{z}$ 193.0837 $[\mathrm{M}+\mathrm{Na}]^{+}$, indicating three degrees of unsaturation. The ${ }^{13} \mathrm{C}$ NMR spectrum showed nine carbon signals ascribable for a carbonyl group, a double bond, two methylenes, two methines, and two methyls (Table 4). On the basis of the above evidence, compound $\mathbf{1 1}$ was suggested to be a single ring molecule. In the ${ }^{1} \mathrm{H}-{ }^{1} \mathrm{H}$ COSY spectrum, a fragment of $\mathrm{CH}_{3}-\mathrm{CH}-\mathrm{CH}_{2}-\mathrm{CH}-$ was established readily, while the HMBC correlation of $\delta_{\mathrm{H}} 5.40(1 \mathrm{H}, \mathrm{m}, \mathrm{H}-5)$ with $\delta_{\mathrm{C}} 180.1(\mathrm{~s}, \mathrm{C}-2)$ established a five-membered lactone ring. In addition, the HMBC correlations of a methyl signal at $\delta_{\mathrm{H}} 1.82(3 \mathrm{H}, \mathrm{s}, \mathrm{H}-9)$ and an oxygenated methylene signals at $\delta_{\mathrm{H}} 4.20(1 \mathrm{H}, \mathrm{d}, J=$ $12.0 \mathrm{~Hz}, \mathrm{H}-10 \mathrm{a})$ and $4.17(1 \mathrm{H}, \mathrm{d}, J=12.0 \mathrm{~Hz}, \mathrm{H}-10 \mathrm{~b})$ with $\delta_{\mathrm{C}}$ 125.7 (d, C-7) suggested the existence of an oxygenated isobutylene group connected to $\mathrm{C}-5$. The ROESY correlations of $\mathrm{H}-5 / \mathrm{H}-4 \mathrm{a}$ and $\mathrm{H}-4 \mathrm{~b} / \mathrm{H}-3$ suggested that $\mathrm{H}-3$ and $\mathrm{H}-5$ were in the opposite side, while the ROESY correlation between $\mathrm{H}-7$ and $\mathrm{H}-9$ indicated the $Z$-form of the double bond of $\mathrm{C}(7)=\mathrm{C}(8)$. Therefore, compound $\mathbf{1 1}$ was established as 6-methyl-5-(10oxymethylene-isobutylene)-lactone.

Compound 12, a colorless oil, possessed a molecular formula $\mathrm{C}_{11} \mathrm{H}_{16} \mathrm{O}_{4}$, as established on the basis of ESIMS $(\mathrm{m} / \mathrm{z}$ $\left.235[\mathrm{M}+\mathrm{Na}]^{+}\right)$, in combination with 1D NMR and HSQC spectra analysis. According to the NMR data (Table 4), compound 12 was readily identified as the acetoxylated product of 11. The acetoxyl group was identified to be connected to C-10 on the basis of HMBC correlation of $\delta_{\mathrm{H}}$ 4.78 and 4.50 (each $1 \mathrm{H}, \mathrm{d}, J=12.5 \mathrm{~Hz}, \mathrm{H}-10$ ) with $\delta_{\mathrm{C}} 171.0$ (s, OAc). Detailed analysis of 2D NMR data (HSQC, HMBC, ROESY) indicated the other parts were the same to those of $\mathbf{1 1}$. Therefore, compound 12 was determined to 6-methyl-5-(10-Oacetyl-isobutylene)-lactone.

Table 4. ${ }^{1} \mathrm{H}$ and ${ }^{13} \mathrm{C}$ NMR data of compounds 11 and $12\left(\mathrm{CDCl}_{3}\right.$, $\delta$ in ppm and $J$ in $\mathrm{Hz}$ )

\begin{tabular}{llrlr}
\hline & \multicolumn{3}{c}{$\mathbf{1 1}$} & \multicolumn{3}{c}{$\mathbf{1 2}$} \\
\cline { 2 - 5 } \multicolumn{1}{c}{ position } & \multicolumn{1}{c}{$\delta_{\mathrm{H}}$} & \multicolumn{1}{c}{$\delta_{\mathrm{C}}$} & \multicolumn{1}{c}{$\delta_{\mathrm{H}}$} & $\delta_{\mathrm{C}}$ \\
\hline 2 & & $180.1(\mathrm{~s})$ & & $180.0(\mathrm{~s})$ \\
3 & $2.77(\mathrm{~m})$ & $34.5(\mathrm{~d})$ & $2.72(\mathrm{~m})$ & $34.3(\mathrm{~d})$ \\
$4 \mathrm{a}$ & $2.21(\mathrm{~m})$ & $37.3(\mathrm{t})$ & $2.15(\mathrm{~m})$ & $37.1(\mathrm{t})$ \\
$4 \mathrm{~b}$ & $2.13(\mathrm{~m})$ & & $2.10(\mathrm{~m})$ & \\
5 & $5.40(\mathrm{~m})$ & $74.1(\mathrm{~d})$ & $5.34(\mathrm{~m})$ & $74.1(\mathrm{~d})$ \\
6 & $1.32(\mathrm{~d}, 6.0)$ & $15.9(\mathrm{q})$ & $1.31(\mathrm{~d}, 6.0)$ & $15.9(\mathrm{q})$ \\
7 & $5.41(\mathrm{br} . \mathrm{s})$ & $125.7(\mathrm{~d})$ & $5.48(\mathrm{~d}, 8.7)$ & $127.9(\mathrm{~d})$ \\
8 & & $142.0(\mathrm{~s})$ & & $136.7(\mathrm{~s})$ \\
9 & $1.88(\mathrm{~s})$ & $21.6(\mathrm{~s})$ & $1.80(\mathrm{~s})$ & $21.7(\mathrm{~s})$ \\
$10 \mathrm{a}$ & $4.26(\mathrm{~d}, 12.0)$ & $62.1(\mathrm{t})$ & $4.78(\mathrm{~d}, 12.5)$ & $62.7(\mathrm{t})$ \\
$10 \mathrm{~b}$ & $4.22(\mathrm{~d}, 12.0)$ & & $4.50(\mathrm{~d}, 12.5)$ & \\
$10-\mathrm{OCOCH}_{3}$ & & & $2.09(\mathrm{~s})$ & $21.1(\mathrm{q})$ \\
$10-\mathrm{OCOCH}_{3}$ & & & & $171.0(\mathrm{~s})$ \\
\hline
\end{tabular}

Compounds $2,3,6,8,10$, and 13 were evaluated for their cytotoxicity against five human cancer cell lines using the MTT method as reported previously. ${ }^{12}$ Unfortunately, no compound showed significant activity $\left(\mathrm{IC}_{50}\right.$ values $\left.>8 \mu \mathrm{M}\right)$. In addition, the inhibitory effects of all the compounds on human and mouse $11 \beta$-HSD1 were also investigated. As a result, boreovibrin $\mathrm{F}$ (6) showed moderate inhibitory activities against $11 \beta$-HSD1 (human $\mathrm{IC}_{50}=46.7 \mu \mathrm{M}$; mouse $\mathrm{IC}_{50}=66.4$ $\mu \mathrm{M})$, while boreovibrin $\mathrm{E}$ (5) and 6-methyl-5-(10oxymethylenes-isobutylene)-lactone (11) showed weak activities (46.8\% and $41.6 \%$ inhibitions at $1.0 \mu \mathrm{M}$, respectively) against human $11 \beta$-HSD1.

\section{會 Springer}




\section{Experimental Section}

General Experimental Procedures. Optical rotations (OR) were recorded on a Jasco P-1020 digital polarimeter. UV data were obtained on a Shimadzu UV-2401A spectrophotometer. Infrared spectroscopy (IR) spectra were obtained on a Bruker Tensor 27 FT-IR spectrometer with $\mathrm{KBr}$ pellets. Nuclear Magnetic Resonance (NMR) spectra were obtained on Bruker AV-400 and DRX-500 instruments, and a Bruker Avance III $600 \mathrm{MHz}$ spectrometer with tetramethylsilane (TMS) as an internal standard at room temperature. Mass spectra were recorded on a VG Autospec-3000 mass spectrometer and an API QSTAR Pulsar I spectrometer. Silica gel (200-300 mesh, Qingdao Marine Chemical Ltd., China) and Sephadex LH-20 (Amersham Biosciences, Sweden) were used for open column chromatography (CC). Fractions were monitored by TLC. Spots were visualized by heating silica gel plates immersed in Vanillin- $\mathrm{H}_{2} \mathrm{SO}_{4}$ in ethanol.

Fungal Material and Cultivation Conditions. B. vibrans was provided and fermented by Zheng-Hui Li, Kunming Institute of Botany. A voucher specimen was deposited in the Herbarium of Kunming Institute of Botany, Chinese Academy of Sciences. The culture medium consisted of glucose $(5 \%)$, peptone from porcine meat $(0.15 \%)$, yeast powder $(0.5 \%)$, $\mathrm{KH}_{2} \mathrm{PO} 4(0.05 \%)$ and $\mathrm{MgSO} 4(0.05 \%)$. The fungus was grown in seeding tank (inoculation volume 10\%, $250 \mathrm{rpm}$, $24{ }^{\circ} \mathrm{C}$, aeration $1.0 \mathrm{vvm}, 6$ days). Fermentation was carried out in a fermenter ( $60 \mathrm{~L}$ working volume) for 20 days.

Extraction and Isolation. The culture broth $(60 \mathrm{~L})$ was filtered, and the filtrate was extracted three times with EtOAc while the mycelium was extracted three times with $\mathrm{CH}_{3} \mathrm{Cl}$ $\mathrm{MeOH}(1: 1)$. The EtOAc layer together with the mycelium extraction was concentrated under reduced pressure to give a crude extract $(62 \mathrm{~g})$, and this residue was subjected to $\mathrm{CC}$ over silica gel (200-300 mesh) eluted with a gradient of $\mathrm{CH}_{3} \mathrm{Cl}-$ $\mathrm{MeOH}(1: 0 \rightarrow 0: 1)$ to obtain five fractions $(1-5)$. Fraction 3 was first separated by silica gel $\mathrm{CC}$ eluted with petroleum ether/Acetone gradient $(6: 1 \rightarrow 3: 1, \mathrm{v} / \mathrm{v})$, then prepared by reverse-phased $\mathrm{RP}-18 \mathrm{CC}\left(\mathrm{MeOH} / \mathrm{H}_{2} \mathrm{O}, 5: 5 \rightarrow 9: 1, \mathrm{v} / \mathrm{v}\right)$ and Sephadex LH-20 $\left(\mathrm{CHCl}_{3} / \mathrm{MeOH}, 1: 1\right)$ to afford $13(30.0 \mathrm{mg})$, $\mathbf{2}(2.8 \mathrm{mg}), \mathbf{1 1}(2.2 \mathrm{mg}), \mathbf{1}(2.2 \mathrm{mg}), \mathbf{6}(2.2 \mathrm{mg}), \mathbf{5}(1.0 \mathrm{mg}), \mathbf{7}$ $(1.7 \mathrm{mg}), \mathbf{8}(2.0 \mathrm{mg}), \mathbf{1 0}(2.2 \mathrm{mg}), \mathbf{1 2}(0.7 \mathrm{mg}), \mathbf{4}(2.0 \mathrm{mg})$, and 9 (4.6 mg). Fraction 4 was separated repeatedly by reverse-phased $\mathrm{RP}-18 \mathrm{CC}\left(\mathrm{MeOH} / \mathrm{H}_{2} \mathrm{O}, 3: 7, \mathrm{v} / \mathrm{v}\right)$, followed by Sephadex LH-20 $\left(\mathrm{CHCl}_{3} / \mathrm{MeOH}, 1: 1\right)$ to give $3(2.7 \mathrm{mg})$.

Boreovibrin A (1): colorless oil; $[\alpha]_{\mathrm{D}}^{17}+14.6$ (c 0.28 , $\mathrm{MeOH})$; IR (KBr) $v_{\max } 3431,2925,1707,1628,1461,1237$, $1125 \mathrm{~cm}^{-1}$; ${ }^{1} \mathrm{H}(600 \mathrm{MHz})$ and ${ }^{13} \mathrm{C}(150 \mathrm{MHz})$ data $\left(\mathrm{CDCl}_{3}\right)$ see Tables 1 and 2; HREIMS $\mathrm{m} / z 252.1729$ [M] $^{+}$(calcd for $\left.\mathrm{C}_{15} \mathrm{H}_{24} \mathrm{O}_{3}, 252.1725\right)$.

Boreovibrin B (2): colorless oil; $[\alpha]_{\mathrm{D}}^{17}+32.2$ (c 0.28 , $\mathrm{MeOH})$; IR (KBr) $v_{\max } 3472,2949,2927,1711,1627,1459$, $1207,1130 \mathrm{~cm}^{-1} ;{ }^{1} \mathrm{H}(600 \mathrm{MHz})$ and ${ }^{13} \mathrm{C}(150 \mathrm{MHz})$ data (acetone- $d_{6}$ ) see Tables 1 and 2; positive ion HRESIMS $\mathrm{m} / \mathrm{z}$ $275.1618[\mathrm{M}+\mathrm{Na}]^{+}$(calcd for $\mathrm{C}_{15} \mathrm{H}_{24} \mathrm{O}_{3} \mathrm{Na}, 275.1623$ ).
Boreovibrin C (3): colorless oil; $[\alpha]_{\mathrm{D}}^{16}+23.5$ (c 0.27, $\mathrm{MeOH})$; IR (KBr) $v_{\max } 3432,2935,2938,1736,1618,1460$, $1379,1238,1026 \mathrm{~cm}^{-1} ;{ }^{1} \mathrm{H}(400 \mathrm{MHz})$ and ${ }^{13} \mathrm{C}(125 \mathrm{MHz})$ data $\left(\mathrm{CDCl}_{3}\right)$ see Tables 1 and 2; positive ion HRESIMS $\mathrm{m} / \mathrm{z}$ $333.1672[\mathrm{M}+\mathrm{Na}]^{+}$(calcd for $\mathrm{C}_{17} \mathrm{H}_{26} \mathrm{O}_{5} \mathrm{Na}, 333.1677$ ).

Boreovibrin D (4): colorless oil; $[\alpha]_{\mathrm{D}}^{18}+11.2$ (c 0.20 , $\mathrm{MeOH})$; IR (KBr) $v_{\text {max }} 3424,2929,1739,1705,1646,1453$, $1378,1235,1025 \mathrm{~cm}^{-1} ;{ }^{1} \mathrm{H}(600 \mathrm{MHz})$ and ${ }^{13} \mathrm{C}(150 \mathrm{MHz})$ data (acetone- $d_{6}$ ) see Tables 1 and 2; negative ion HRESIMS $m / z 291.1589[\mathrm{M}-\mathrm{H}]^{-}$(calcd for $\mathrm{C}_{17} \mathrm{H}_{23} \mathrm{O}_{4}, 291.1596$ ).

Boreovibrin E (5): colorless oil; $[\alpha]_{\mathrm{D}}^{19}-50.2$ (c 0.10, $\mathrm{MeOH})$; IR (KBr) $v_{\max } 3443,2932,1740,1639,1449,1376$, $1239,1052 \mathrm{~cm}^{-1} ;{ }^{1} \mathrm{H}(600 \mathrm{MHz})$ and ${ }^{13} \mathrm{C}(150 \mathrm{MHz})$ data $\left(\mathrm{CDCl}_{3}\right)$ see Tables 1 and 2; negative ion HRESIMS $\mathrm{m} / \mathrm{z}$ $307.1554[\mathrm{M}-\mathrm{H}]^{-}$(calcd for $\left.\mathrm{C}_{17} \mathrm{H}_{23} \mathrm{O}_{5}, 307.1545\right)$.

Boreovibrin F (6): colorless oil; $[\alpha]_{\mathrm{D}}^{16}+38.1$ (c 0.31 , $\mathrm{MeOH})$; IR (KBr) $v_{\max } 3455,2964,2938,1739,1619,1460$, $1370,1239,1036 \mathrm{~cm}^{-1} ;{ }^{1} \mathrm{H}(400 \mathrm{MHz})$ and ${ }^{13} \mathrm{C}(100 \mathrm{MHz})$ data $\left(\mathrm{CDCl}_{3}\right)$ see Tables 1 and 2; positive ion HRESIMS $\mathrm{m} / \mathrm{z}$ $361.1995[\mathrm{M}+\mathrm{Na}]^{+}$(calcd for $\mathrm{C}_{19} \mathrm{H}_{30} \mathrm{O}_{5} \mathrm{Na}, 361.1990$ ).

Boreovibrin G (7): colorless oil; $[\alpha]_{\mathrm{D}}^{18}+24.98$ (c 0.17 , $\mathrm{MeOH})$; IR (KBr) $v_{\max } 3425,2955,2933,1736,1641,1452$, $1376,1242,1027 \mathrm{~cm}^{-1} ;{ }^{1} \mathrm{H}(600 \mathrm{MHz})$ and ${ }^{13} \mathrm{C}(150 \mathrm{MHz})$ data $\left(\mathrm{CDCl}_{3}\right)$ see Tables 1 and 2; positive ion HRESIMS $\mathrm{m} / \mathrm{z}$ $319.1885[\mathrm{M}+\mathrm{Na}]^{+}$(calcd for $\mathrm{C}_{17} \mathrm{H}_{28} \mathrm{O}_{4} \mathrm{Na}, 319.1885$ ).

5-(1"-Acetyloxymethylene)-2-hydroxyisopropenyl-2,3dihydrobenzofuran (8): colorless oil; $[\alpha]_{\mathrm{D}}^{16}+18.1$ (c 0.20 , $\mathrm{MeOH}) ; \mathrm{UV}(\mathrm{MeOH}) \lambda_{\max }(\log \varepsilon) 202$ (3.78), 232 (3.23), 284 (2.76) nm; IR (KBr) $v_{\max } 3431,2925,1737,1657,1639,1614$ 1548, 1492, 1249, $1025 \mathrm{~cm}^{-1} ;{ }^{1} \mathrm{H}(400 \mathrm{MHz})$ and ${ }^{13} \mathrm{C}(125$ MHz) data $\left(\mathrm{CDCl}_{3}\right)$ see Table 3; HREIMS $\mathrm{m} / z$ 248.1037 [M] (calcd for $\mathrm{C}_{14} \mathrm{H}_{16} \mathrm{O}_{4}, 248.1049$ ).

5-(1"-Acetyloxymethylene)-2-(1,2-dihydroxyisopropyl)2,3-dihydrobenzofuran (9): colorless oil; $[\alpha]_{\mathrm{D}}^{17}+21.97(c$ 0.46, MeOH); UV (MeOH) $\lambda_{\max }(\log \varepsilon) 202$ (3.47), 232 (2.89), 284 (2.45), $368(1.27) \mathrm{nm}$; IR (KBr) $v_{\max } 3424,2931,1736$ 1615, 1494, 1239, $1027 \mathrm{~cm}^{-1} ;{ }^{1} \mathrm{H}(600 \mathrm{MHz})$ and ${ }^{13} \mathrm{C}$ $(150 \mathrm{MHz})$ data (acetone- $\left.d_{6}\right)$ see Table 3 ; negative ion HRESIMS $\mathrm{m} / z 265.1072[\mathrm{M}-\mathrm{H}]^{-}$(calcd for $\mathrm{C}_{14} \mathrm{H}_{17} \mathrm{O}_{5}$, 265.1075).

5-(1"-Acetyloxymethylene)-2-(1-O-acetyl-1,2-hydroxyisopropyl)-2,3-dihydrobenzofuran (10): colorless oil; $[\alpha]_{\mathrm{D}}^{16}+$ 29.4 (c 0.22, $\mathrm{MeOH}) ; \mathrm{UV}(\mathrm{MeOH}) \lambda_{\max }(\log \varepsilon) 202$ (3.60), 232 (3.05), 283 (2.57) nm; IR (KBr) $v_{\max } 3444,2928,1738,1657$ $1638,1616,1550,1494,1239,1028 \mathrm{~cm}^{-1} ;{ }^{1} \mathrm{H}(400 \mathrm{MHz})$ and ${ }^{13} \mathrm{C}(125 \mathrm{MHz})$ data $\left(\mathrm{CDCl}_{3}\right)$ see Table 3 ; positive ion HREIMS $m / z 308.1262[\mathrm{M}]^{+}$(calcd for $\mathrm{C}_{16} \mathrm{H}_{20} \mathrm{O}_{6}, 308.1260$ ).

6-Methyl-5-(10-oxymethylene-isobutylene)-lactone (11): colorless oil; $[\alpha]_{\mathrm{D}}^{17}+22.5($ c $0.28, \mathrm{MeOH})$; IR $(\mathrm{KBr}) v_{\max } 3426$, 
2934, 1767, 1453, 1380,1189, $1040 \mathrm{~cm}^{-1} ;{ }^{1} \mathrm{H}(400 \mathrm{MHz})$ and ${ }^{13} \mathrm{C}(150 \mathrm{MHz})$ data $\left(\mathrm{CDCl}_{3}\right)$ see Table 4 ; positive ion HRESIMS $m / z 193.0837[\mathrm{M}+\mathrm{Na}]^{+}$(calcd for $\mathrm{C}_{9} \mathrm{H}_{14} \mathrm{O}_{3} \mathrm{Na}$, 193.0840).

6-Methyl-5-(10-O-acetyl-isobutylene)-lactone (12): colorless oil; $[\alpha]_{\mathrm{D}}^{17}+34.0$ (c $\left.0.07, \mathrm{MeOH}\right)$; IR (KBr) $v_{\max } 3441$, 2934, 1772, 1740, 1453, 1378, 1234, $1192 \mathrm{~cm}^{-1} ;{ }^{1} \mathrm{H}(600 \mathrm{MHz})$ and ${ }^{13} \mathrm{C}(150 \mathrm{MHz})$ data $\left(\mathrm{CDCl}_{3}\right)$ see Table 4 ; positive ion ESIMS $m / z 235[\mathrm{M}+\mathrm{Na}]^{+}$.

Cytotoxicity Assay. Five human cancer cell lines: breast cancer SK-BR-3, hepatocellular carcinoma SMMC-7721, human myeloid leukemia HL-60, pancreatic cancer PANC-1, and lung cancer A-549 cells, were used in the cytotoxic assay. Cells were cultured in RPMI-1640 or in DMEM medium (Hyclone, USA), supplemented with $10 \%$ fetal bovine serum (Hyclone, USA) in $5 \% \mathrm{CO}_{2}$ at $37^{\circ} \mathrm{C}$. The cytotoxicity assay was performed according to the MTT (3-(4,5-dimethylthiazol2-yl)-2,5-diphenyl tetrazolium bromide) method in 96-well microplates. ${ }^{12}$ Briefly, $100 \mu \mathrm{L}$ of adherent cells were seeded into each well of 96-well cell culture plates and allowed to adhere for $12 \mathrm{~h}$ before addition of test compounds, while suspended cells were seeded just before drug addition with initial density of $1 \times 10^{5}$ cells $/ \mathrm{mL}$. Each tumor cell line was exposed to the test compound at concentrations of $0.0625,0.32,1.6$, and $8 \mu \mathrm{M}$ in triplicates for $48 \mathrm{~h}$, with cisplatin (sigma, USA) as positive control. After compound treatment, cell viability was detected and a cell growth curve was graphed. $\mathrm{IC}_{50}$ values were calculated by Reed and Muench's method. ${ }^{13}$

Inhibition on 11/-HSD1 Activity Assays. The inhibition activity of compounds on human or mouse $11 \beta$-HSD 1 enzymatic activities was determined in the scintillation proximity assay (SPA) using microsomes containing $11 \beta$ HSD1 as described in previous studies. ${ }^{14}$ Briefly, the full fulllength cDNAs of human or murine $11 \beta$-HSD1 were isolated from the cDNA libraries provided by the NIH Mammalian Gene Collection and cloned into a pcDNA3 expression vector. HEK-293 cells were transfected with the pcDNA3-derived expression plasmid and selected after cultivation in the presence of $700 \mu \mathrm{g} / \mathrm{mL}$ of G418. The microsomal fraction overexpressing $11 \beta$-HSD1 was prepared from the HEK-293 cells stably transfected with $11 \beta$-HSD1 and used as the enzyme source for Scintillation Proximity Assay (SPA). Microsomes containing human or mouse $11 \beta$-HSD1 were incubated with NADPH and $\left[{ }^{3} \mathrm{H}\right]$ cortisone, and then the product $\left[{ }^{3} \mathrm{H}\right]$ cortisol was specifically captured by a monoclonal antibody coupled to protein A-coated SPA beads. All experiments were done in duplicate with glycyrrhizininc acid as a positive control. $\mathrm{IC}_{50}$ $( \pm$ S.D., $n=2)$ values were calculated using Prism Version 4 (GraphPad Software, San Diego, CA, U.S.A.). $\mathrm{IC}_{50}$ values of glycyrrhizininc acid (positive control) are 5.41, and $8.42 \mathrm{nM}$ for mouse $11 \beta$-HSD1, and human $11 \beta$-HSD1, respectively.

\section{Electronic Supplementary Material}

Supplementary material is available in the online version of this article at http://dx.doi.org/ 10.1007/s13659-012-0060-x and is accessible for authorized users.

\section{Acknowledgments}

This work was financially supported by National Basic Research Program of China (973 Program, 2009CB522300), the National Natural Science Foundation of China (30830113, U1132607).

Open Access This article is distributed under the terms of the Creative Commons Attribution License which permits any use, distribution, and reproduction in any medium, provided the original author(s) and source are credited.

\section{References}

[1] Liu, D. Z.; Wang, F.; Liao, T. G.; Tang, J. G.; Steglich, W.; Zhu, H. J.; Liu, J. K. Org. Lett. 2006, 8, 5749-5752.

[2] Jiang, M. Y.; Wang, F.; Yang, X. L.; Fang, L. Z.; Dong, Z. J.; Zhu, H. J.; Liu, J. K. Chem. Pharm. Bull. 2008, 56, 1286-1288.

[3] Jiang, M. Y.; Zhang, L.; Dong, Z. J.; Yang, Z. L.; Leng, Y.; Liu, J. K. Chem. Pharm. Bull. 2010, 58, 113-116.

[4] Wang, G. Q.; Wei, K.; Feng, T.; Li, Z. H.; Zhang, L.; Wang, Q. A.; Liu, J. K. J. Asian Nat. Prod. Res. 2012, 14, 115-120.

[5] Zhou, Q.; Snider, B. B. Org. Lett. 2008, 10, 1401-1404.

[6] Zeiler, E.; Braun, N.; Boettcher, T.; Kastenmueller, A.; Weinkauf, S.; Sieber, S. A. Angew. Chem. Int. Ed. 2011, 50, 11001-11004.

[7] Donnelly, D. M. X.; Fukuda, N.; Kouno, I.; Martin, M.; O'Reilly, J. Phytochemistry 1988, 27, 2709-2713.

[8] Kuo, Y. H.; Wu, T. R.; Cheng, M. C.; Wang, Y. Chem. Pharm. Bull. 1990, 38, 3195-3201.

[9] Brown, G. D.; Sy, L. K. Tetrahedron 2004, 60, 1125-1138.

[10] (a) Brown, G. D. J. Nat. Prod. 1992, 55, 1756-1760. (b) Xie, B. J.; Yang, S. P.; Yue, J. M. Phytochemistry 2008, 69, 2993-2997.

[11] Hirotani, M.; O'Reilly, J.; Donnelly, D. M. X.; Polonsky, J. Tetrahedron Lett. 1977, 7, 651-652.

[12] Mosmann, T. J. Immunol. Methods 1983, 65, 55-63.

[13] Reed, L. J.; Muench, H. Am. J. Hygiene 1938, 27, 493-497.

[14] Yang H.; Dou W.; Lou J.; Leng Y.; Shen J. Bioorg. Med. Chem. Lett. 2008, 18, 1340-1345.

\section{照 Springer}

